\title{
LAGGED EFFECTS OF WINTER CATCH CROPS FOLLOWED BY SWEET CORN (ZEA MAYS L. VAR. SACCHARATA KORN.) AND SUBSEQUENTLY SPRING BROCCOLI (BRASSICA OLERACEA L. VAR. ITALICA PLENCK)
}

\author{
ROSA, R. ${ }^{*}$ - FRANCZUK, J. - ZANIEWICZ-BAJKOWSKA, A. \\ Siedlce University of Natural Sciences and Humanities, Faculty of Agrobioengineering and \\ Animal Husbandry, Prusa 14 Street, 08-110 Siedlce, Poland \\ (e-mail:warzywa@uph.edu.pl) \\ ${ }^{*}$ Corresponding author \\ e-mail: robert.rosa@uph.edu.pl; ORCIDID:0000-0001-6344-538X
}

(Received $27^{\text {th }}$ Nov 2019; accepted $23^{\text {rd }}$ Mar 2020)

\begin{abstract}
This paper deals with lagged effects of winter catch crops on the growth, yield, and quality of spring broccoli. In the first year of the experiment (2008-2010), hairy vetch (VV), white clover (TR), winter rye (SC), and Italian ryegrass (LM) were sown as winter catch crops. In the next spring (2009-2011) they were ploughed into the soil, and sweet corn was grown on plots with incorporated catch crops. To other sweet corn plots farmyard manure was applied at a dose of $30 \mathrm{t} \cdot \mathrm{ha}^{-1}$. Finally, sweet corn was followed by the Loreto $F_{1}$ and Milady $F_{1}$ varieties of broccoli in 2010-2012. The effect of the catch crops was compared with the control plants (with no organic fertilizer) and that of the effect of manure. Manure application resulted in the highest broccoli yield. However, a statistically similar marketable yield of curds was also recorded on plots with the incorporated catch crops of hairy vetch, white clover, and winter rye. Grown in the second year after the incorporation of SC, VV, and manure they were richer in protein, and those grown after VV and TR contained more total sugars than the control plants. The largest concentration of $\mathrm{P}$ was found in broccoli grown after VV and TR as catch crops, $\mathrm{K}$ in plants following VV and manure, and $\mathrm{Mg}$ in those following VV. It was found that hairy vetch, white clover, and winter rye could be used as organic fertilizers, alternatives for manure. Their growth promoting effect extends to the second year after their incorporation.
\end{abstract}

Keywords: FYM, green manure, nutritional value, organic fertilisation, yield

\section{Introduction}

Broccoli (Brassica oleracea var. italica) is an important vegetable grown worldwide. The plant originates from the Mediterranean region and belongs to the Brassicaceae family. Considered to be a valuable source of vitamins, antioxidants, glucosinolates, and other compounds with proven anticancer activity, it is tasty and more nutritious than any other vegetable of the same kind (Parente et al., 2013). Today, the broccoli market is growing steadily all over the world since consumers find its curds an important component of a healthy diet. Over the last 35 years, the consumption of fresh broccoli has increased so much that now it is the 11th most consumed fresh vegetable.

The worldwide production of broccoli (and cauliflower) is 26.5 million tonnes. The main producer is China, with a $40 \%$ share in the volume of global production. The top 10 countries producing fresh broccoli are China, India, USA, Spain, Mexico, Italy, France, Poland, Bangladesh and Turkey (FAOSTAT, 2019). In Poland approx. 15\% the total European broccoli is produced, but the largest producer in Europe is Spain, with a share of $37 \%$. Due to the of growing demand for high-quality products and an increase in environmental awareness, agricultural producers use more environmentally friendly production methods. One of the priorities is enriching the soil with organic matter, which 
restores soil fertility and increases its buffer properties. The production of fertilisers of animal origin across Europe is insufficient, and, therefore, increasing attention is paid again to green fertilisers of plant origin (Talgre et al., 2012; Fekete and Pepó, 2018; Thavarajah et al., 2019). Green manure should become a permanent element of improving soil fertility in the integrated and organic farming systems. It is a factor that alleviates the negative effect of farming intensification, excessive soil compaction, and one-sided mineral fertilization (Kristensen and Thorup-Kristensen, 2004; Rogers et al., 2004; Choi et al., 2014). Catch crops also have a many-sided effect on biological, physical and chemical soil properties. They reduce erosion, build soil organic matter, and positively influence soil organisms (Snapp et al., 2005; Reddy, 2016). Catch crops protect the forms of nutrients easily available for plants from leaching into deeper layers of the soil profile and into groundwater. During the process of catch crop mineralization, biomass $\mathrm{N}$ is gradually released and becomes available for the subsequent plants (Vos and van der Putten, 2001; Reddy, 2016; Iivonen et al., 2017).

Some studies have shown that the use of green fertilizers allows not only the achievement satisfactory yields of subsequent vegetable plants, but also improves their quality and nutritional value (Jabłońska-Ceglarek and Rosa, 2003; AdamczewskaSowińska and Kołota, 2008; Zhang et al., 2010).

The purpose of this research was to determine the effect of winter catch crops on the size and quality of the broccoli yield.

\section{Material and Methods}

\section{Experimental site}

A field experiment was carried out from 2008 to 2012 at the Experimental Farm of the Siedlce University of Natural Sciences and Humanities, located in central eastern Poland $\left(52^{\circ} 03^{\prime} \mathrm{N}, 22^{\circ} 33^{\prime} \mathrm{E}\right)$ (Figure 1). The soil was classified as Luvisol (IUSS, 2015), with the average organic carbon content of $0.99 \%$, the humus layer reaching a depth of 30-40 cm, and $\mathrm{pH}_{\mathrm{KCl}}$ of 6.2. Total macronutrient content in air dried matter amounted to $61 \mathrm{mg}$ of $\mathrm{N}\left(\mathrm{NO}_{3}+\mathrm{NH}_{4}\right), 63 \mathrm{mg}$ of $\mathrm{P}, 73 \mathrm{mg}$ of $\mathrm{K}, 31 \mathrm{mg}$ of $\mathrm{Mg}$, and $255 \mathrm{mg}$ of Ca per $1 \mathrm{dm}^{3}$.

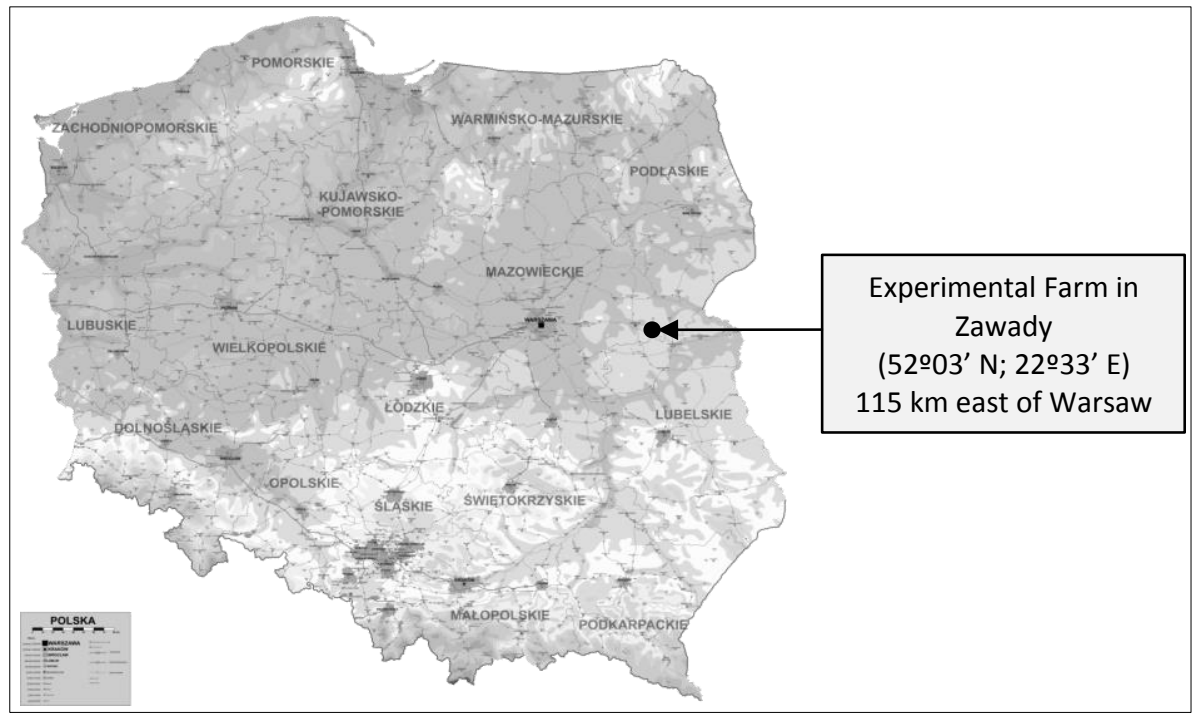

Figure 1. Location of the Experimental Farm 


\section{Experimental design}

The experiment was established in a split-block design with three replicates, and it included two factors: factor I - broccoli cultivar, factor II - organic manure (Table 1). In the autumn each year between 2008 and 2010 catch crops were sown. They were incorporated each spring between 2009 and 2011 and followed by sweet corn. At the same time, farmyard manure at a dose of $30 \mathrm{t} \cdot \mathrm{ha}^{-1}$ was applied prior to planting sweet corn on other plots. Broccoli was grown between 2010 and 2012, each time in the second year after the incorporation of winter catch crops and manure. Detailed dates and succession of crops are listed in Table 2. The content of minerals in the catch crops and in the farmyard manure is presented in Table 3. The direct impact of the incorporated green fertilizers on the growth, yields and nutritional value of sweet corn has been described in previous publications (Rosa, 2014, 2015).

Table 1. Factors of the experiment

\begin{tabular}{|c|c|c|}
\hline \multirow{3}{*}{ Factor I } & \multicolumn{2}{|r|}{ Broccoli cultivars: } \\
\hline & Loreto $\mathrm{F}_{1}$ & $\begin{array}{c}\text { This cultivar is grown for summer and autumn harvests, with the first fully grown curds } \\
\text { after } 65 \text { days. The plant is tall, strong, with leaves erected, producing large curds with a } \\
\text { mass reaching } 750 \mathrm{~g} \text {. It is highly resistant to downy mildew and wet rot. Seminis } \\
\text { Vegetable Seeds, Bayer Group. }\end{array}$ \\
\hline & Milady $F_{1}$ & $\begin{array}{l}\text { This cultivar is especially recommended for early-spring cultivation. Curds are ready for } \\
\text { harvesting about } 60 \text { days after seedling planting. It produces curds of similar sizes, } \\
\text { weighing more than } 400 \text { g. Plants do not form hollowed stems, and they are resistant to } \\
\text { downy mildew and wet rot. Seminis Vegetable Seeds, Bayer Group. }\end{array}$ \\
\hline \multirow{7}{*}{ Factor II } & \multicolumn{2}{|r|}{ Organic fertilizer: } \\
\hline & Control & Without organic fertilizer. \\
\hline & FYM & Farmyard manure applied at a rate of $30 \mathrm{t} \cdot \mathrm{ha}^{-1}$, incorporated in early May 2009-2011. \\
\hline & VV & $\begin{array}{l}\text { Hairy vetch (Vicia villosa } \text { Roth.) winter catch crop - seeds sown in early September at a } \\
\text { rate of } 70 \mathrm{~kg} \cdot \mathrm{ha}^{-1} \text {, incorporated in early May 2009-2011. }\end{array}$ \\
\hline & TR & $\begin{array}{c}\text { White clover (Trifolium repens L.) winter catch crop - seeds sown in early September at a } \\
\text { rate of } 20 \mathrm{~kg} \cdot \mathrm{ha}^{-1} \text {, incorporated in early May 2009-2011. }\end{array}$ \\
\hline & SC & $\begin{array}{c}\text { Winter rye (Secale cereale L.) winter catch crop - seeds sown in early September at a rate } \\
\text { of } 180 \mathrm{~kg} \cdot \mathrm{ha}^{-1} \text {, incorporated in early May } 2009-2011 .\end{array}$ \\
\hline & LM & $\begin{array}{l}\text { Italian ryegrass (Lolium multiflorum L.) winter catch crops - seeds sown in early } \\
\text { September at a rate of } 35 \mathrm{~kg} \cdot \mathrm{ha}^{-1} \text {, incorporated in early May 2009-2011. }\end{array}$ \\
\hline
\end{tabular}

Table 2. Chronology of field operations

\begin{tabular}{|c|c|c|}
\hline $\begin{array}{l}\text { Winter catch crops } \\
\qquad(2008-2011)\end{array}$ & $\begin{array}{c}\text { Catch crops sowing } \\
\text { Catch crops incorporated } \\
\text { (Farmyard manure incorporated) }\end{array}$ & $\begin{array}{l}8 \text { September 2008, } 10 \text { September 2009, } 9 \\
\text { September } 2010 \\
7 \text { May 2009, } 11 \text { May 2010, } 5 \text { May } 2011\end{array}$ \\
\hline $\begin{array}{l}\text { Sweet corn } \\
\text { (2009-2011) }\end{array}$ & $\begin{array}{l}\text { Sweet corn sowing } \\
\text { Sweet corn harvest }\end{array}$ & $\begin{array}{c}14 \text { May 2009, } 24 \text { May 2010, } 11 \text { May } 2011 \\
8 \text { September 2009, } 23 \text { August 2010, } 3 \\
\text { September } 2011\end{array}$ \\
\hline $\begin{array}{c}\vee \\
\text { Broccoli } \\
(2010-2012)\end{array}$ & $\begin{array}{l}\text { Broccoli planting } \\
\text { Broccoli harvest }\end{array}$ & $\begin{array}{l}\text { 15 March 2010, } 17 \text { March 2011, 14 March } \\
2012 \\
19 \text { April 2010, } 15 \text { April 2011, } 20 \text { April } 2012 \\
\text { 14 June 2010, 16 June 2011, } 11 \text { June } 2012\end{array}$ \\
\hline
\end{tabular}


Table 3. The quantity of fresh and dry matter and the amount of macronutrients incorporated with farmyard manure and catch crops

\begin{tabular}{|c|c|c|c|c|c|c|c|c|}
\hline \multirow{2}{*}{$\begin{array}{c}\text { Kind of organic } \\
\text { manure / catch crops }\end{array}$} & \multirow{2}{*}{$\begin{array}{c}\text { Year of } \\
\text { incorporation }\end{array}$} & \multirow{2}{*}{$\begin{array}{c}\text { Fresh } \\
\text { matter } \\
\left(\mathbf{t} \cdot \mathbf{h a}^{-1}\right)\end{array}$} & \multirow{2}{*}{$\begin{array}{c}\text { Dry } \\
\text { matter } \\
\left(\mathbf{t} \cdot \mathbf{h a}^{-1}\right)\end{array}$} & $\mathbf{N}$ & $\mathbf{P}$ & $\mathbf{K}$ & $\mathbf{C a}$ & $\mathrm{Mg}$ \\
\hline & & & & \multicolumn{5}{|c|}{ Accumulation $\left(\mathrm{kg} \cdot \mathrm{ha}^{-1}\right)$} \\
\hline \multirow{4}{*}{$\begin{array}{c}\text { Farmyard manure } \\
\text { (FYM) }\end{array}$} & 2009 & $30.0^{\mathrm{a}}$ & $7.1^{\mathrm{a}}$ & $90.8^{\mathrm{a}}$ & $46.3^{\mathrm{a}}$ & $126.4^{\mathrm{a}}$ & $58.1^{\mathrm{a}}$ & $32.8^{\mathrm{a}}$ \\
\hline & 2010 & $30.0^{\mathrm{a}}$ & $7.6^{\mathrm{a}}$ & $106.4^{\mathrm{a}}$ & $49.7^{\mathrm{a}}$ & $140.0^{\mathrm{a}}$ & $70.1^{\mathrm{a}}$ & $39.1^{\mathrm{a}}$ \\
\hline & 2011 & $30.0^{\mathrm{a}}$ & $8.1^{\mathrm{a}}$ & $120.7^{\mathrm{a}}$ & $53.1^{\mathrm{a}}$ & $133.2^{\mathrm{a}}$ & $64.1^{\mathrm{a}}$ & $45.4^{\mathrm{a}}$ \\
\hline & Mean & $30.0^{\mathrm{CD}}$ & $7.6^{\mathrm{B}}$ & $106.0^{\mathrm{B}}$ & $49.7^{\mathrm{B}}$ & $133.2^{\mathrm{B}}$ & $64.1^{\mathrm{B}}$ & $39.1^{\mathrm{C}}$ \\
\hline \multirow{4}{*}{$\begin{array}{l}\text { Hairy vetch } \\
\text { (VV) }\end{array}$} & 2009 & $18.5^{\mathrm{a}}$ & $2.9^{\mathrm{a}}$ & $105.4^{\mathrm{a}}$ & $11.4^{\mathrm{a}}$ & $38.7^{\mathrm{a}}$ & $26.4^{\mathrm{a}}$ & $5.6^{\mathrm{a}}$ \\
\hline & 2010 & $15.7^{\mathrm{a}}$ & $2.6^{\mathrm{a}}$ & $92.9^{\mathrm{a}}$ & $8.9^{\mathrm{a}}$ & $36.7^{\mathrm{a}}$ & $23.8^{\mathrm{a}}$ & $6.1^{\mathrm{a}}$ \\
\hline & 2011 & $20.0^{\mathrm{a}}$ & $3.4^{\mathrm{a}}$ & $127.7^{\mathrm{a}}$ & $14.3^{\mathrm{a}}$ & $46.0^{\mathrm{a}}$ & $29.0^{\mathrm{a}}$ & $6.8^{\mathrm{a}}$ \\
\hline & Mean & $18.1^{\mathrm{B}}$ & $3.0^{\mathrm{A}}$ & $108.7^{\mathrm{B}}$ & $11.5^{\mathrm{A}}$ & $40.5^{\mathrm{A}}$ & $26.4^{\mathrm{A}}$ & $6.2^{\mathrm{A}}$ \\
\hline \multirow{4}{*}{$\begin{array}{l}\text { White clover } \\
\text { (TR) }\end{array}$} & 2009 & $11.8^{\mathrm{a}}$ & $2.1^{\mathrm{a}}$ & $56.0^{\mathrm{a}}$ & $9.9^{\mathrm{a}}$ & $52.7^{\mathrm{a}}$ & $22.0^{\mathrm{a}}$ & $6.0^{\mathrm{a}}$ \\
\hline & 2010 & $12.4^{\mathrm{a}}$ & $2.4^{\mathrm{a}}$ & $84.8^{\mathrm{a}}$ & $10.4^{\mathrm{a}}$ & $62.7^{\mathrm{a}}$ & $25.1^{\mathrm{a}}$ & $7.4^{\mathrm{a}}$ \\
\hline & 2011 & $10.6^{\mathrm{a}}$ & $1.9^{\mathrm{a}}$ & $52.1^{\mathrm{a}}$ & $8.6^{\mathrm{a}}$ & $47.2^{\mathrm{a}}$ & $20.0^{\mathrm{a}}$ & $5.3^{\mathrm{a}}$ \\
\hline & Mean & $11.6^{\mathrm{A}}$ & $2.1^{\mathrm{A}}$ & $64.3^{\mathrm{A}}$ & $9.6^{\mathrm{A}}$ & $54.2^{\mathrm{A}}$ & $22.4^{\mathrm{A}}$ & $6.2^{\mathrm{A}}$ \\
\hline \multirow{4}{*}{$\begin{array}{l}\text { Winter rye } \\
\text { (SC) }\end{array}$} & 2009 & $36.0^{\mathrm{a}}$ & $8.7^{\mathrm{a}}$ & $167.5^{\mathrm{b}}$ & $60.5^{\mathrm{a}}$ & $182.6^{\mathrm{a}}$ & $61.3^{\mathrm{a}}$ & $30.6^{\mathrm{a}}$ \\
\hline & 2010 & $35.1^{\mathrm{a}}$ & $6.9^{\mathrm{a}}$ & $120.7^{\mathrm{ab}}$ & $54.4^{\mathrm{a}}$ & $150.7^{\mathrm{a}}$ & $55.2^{\mathrm{a}}$ & $25.2^{\mathrm{a}}$ \\
\hline & 2011 & $35.3^{\mathrm{a}}$ & $6.4^{\mathrm{a}}$ & $115.9^{\mathrm{a}}$ & $50.1^{\mathrm{a}}$ & $128.7^{\mathrm{a}}$ & $49.9^{\mathrm{a}}$ & $23.7^{\mathrm{a}}$ \\
\hline & Mean & $35.5^{\mathrm{D}}$ & $7.3^{\mathrm{B}}$ & $134.7^{\mathrm{C}}$ & $55.0^{\mathrm{B}}$ & $154.0^{\mathrm{B}}$ & $55.5^{\mathrm{B}}$ & $26.5^{\mathrm{B}}$ \\
\hline \multirow{4}{*}{$\begin{array}{l}\text { Italian ryegrass } \\
(\mathrm{LM})\end{array}$} & 2009 & $17.8^{\mathrm{a}}$ & $4.2^{\mathrm{b}}$ & $72.5^{\mathrm{a}}$ & $20.5^{\mathrm{a}}$ & $165.5^{\mathrm{b}}$ & $24.1^{\mathrm{a}}$ & $13.3^{\mathrm{a}}$ \\
\hline & 2010 & $9.5^{\mathrm{a}}$ & $1.9^{\mathrm{a}}$ & $31.2^{\mathrm{a}}$ & $10.9^{\mathrm{a}}$ & $99.4^{\mathrm{a}}$ & $11.7^{\mathrm{a}}$ & $7.2^{\mathrm{a}}$ \\
\hline & 2011 & $12.4^{\mathrm{a}}$ & $2.5^{\mathrm{ab}}$ & $43.8^{\mathrm{a}}$ & $13.5^{\mathrm{a}}$ & $128.7^{\mathrm{ab}}$ & $18.4^{\mathrm{a}}$ & $7.9^{\mathrm{a}}$ \\
\hline & Mean & $13.2^{\mathrm{AB}}$ & $2.9^{\mathrm{A}}$ & $49.2^{\mathrm{A}}$ & $15.0^{\mathrm{A}}$ & $131.2^{\mathrm{B}}$ & $18.1^{\mathrm{A}}$ & $9.5^{\mathrm{A}}$ \\
\hline
\end{tabular}

Means followed by different lowercase and uppercase letters in columns differ significantly at $\mathrm{p} \leq 0.05$

\section{Seedling preparation}

Broccoli seedlings were grown in a non-heated greenhouse. Seeds were sown in the successive growing seasons on 15, 17 and 14 March to multi-trays with a size of $400 \times 600 \mathrm{~mm}$ and 54 cells with a diameter of $54 \mathrm{~mm}$. The Aura substrate produced by Hollas - Greenyard Horticulture Poland Ltd. was used for the production of seedlings. It was made of de-acidified 'highmoor' peat with 5.5-6.5 pH and salinity not greater than $2 \mathrm{~g}$ of $\mathrm{NaCl}$ per litre. The substrate was enriched with mineral fertilisers (NPK: 14-16$18 \%$ ) and $\mathrm{Mg}$ (5\%). On average nutrient content in the substrate was as follows $\left(\mathrm{mg} \cdot \mathrm{dm}^{-3}\right): 238 \mathrm{NO}_{3}-\mathrm{N}, 18 \mathrm{NH}_{4}-\mathrm{N}, 70 \mathrm{P}, 207 \mathrm{~K}, 1016 \mathrm{Ca}$, and $158 \mathrm{Mg}$.

\section{Field work}

The crop preceding broccoli was sweet corn (Zea mays L. var. Saccharata), to which organic treatment was applied (organic fertilisers in the form of winter crops and farm manure according to the doses in Table 1) with mineral fertilisers (pre-sowing treatment: $60 \mathrm{~kg} \mathrm{~N}, 50 \mathrm{~kg} \mathrm{P}_{2} \mathrm{O}_{5}, 180 \mathrm{~kg} \mathrm{~K}_{2} \mathrm{O}$ per $1 \mathrm{ha}+$ top dressing of $\left.60 \mathrm{~kg} \mathrm{~N} \cdot \mathrm{ha}^{-1}\right)$. After harvesting the cobs, sweet corn plants were cut down and removed from the field. In the autumn the field was ploughed, and in the spring, two weeks before planting seedlings, disc harrowing was used. After that, mineral fertilizers were applied up to the optimal level for broccoli: $205 \mathrm{~kg} \mathrm{~N}, 145 \mathrm{~kg} \mathrm{P}_{2} \mathrm{O}_{5}, 275 \mathrm{~kg} \mathrm{~K}_{2} \mathrm{O}$ per ha. Plants were planted in the successive study years on the 19,15 and 20 of April, at a spacing of $50 \times 50 \mathrm{~cm}$. The area of a plot (unit) was $8 \mathrm{~m}^{2}(2 \mathrm{~m} \times 4 \mathrm{~m})$, with 32 plants in each. The area of the whole field together with paths between experimental combinations and replicates was $750 \mathrm{~m}^{2}$. After broccoli were planting, they were covered with the polypropylene fibre Pegas Agro 17UV (Rybnik, Poland). The cover was removed after three weeks. Then $50 \mathrm{~kg}$ of N per hectare was applied (top dressing). 


\section{Sample collection and laboratory analysis}

Broccoli was harvested by hand on 14 June in 2010, 16 June in 2011, and 11 June in 2012. The area of each plot to be harvested was $6 \mathrm{~m}^{2}$ (12 plants). The marketable yield, weight of the marketable curd, length of the curd arc, and the stalk diameter were determined after the harvest. From each plot a curd sample was collected (four randomly selected curds) for chemical analysis to determine: dry matter content by drying to the constant weight at $105^{\circ} \mathrm{C}$ (Polish Standard PN-EN 12145, 2001); protein content with the Kjeldahl method, using the 6.25 factor (AOAC, 1984); L-ascorbic acid content with the Tillmans method (PN-A-04019, 1998); total sugars content with the Luff-Schoorl method (EU, 2009). In 2011 and 2012, the content of macronutrients (P, K, Ca and $\mathrm{Mg}$ ) in broccoli was also determined. P content was measured by colorimetry with the SPEKOL 221 spectrophotometer (Carl Zeiss AG, Germany). The content of $\mathrm{K}$ and $\mathrm{Ca}$ was determined with the FLAPHO 41 flame photometer (Carl Zeiss AG, Germany). The content of Mg was determined with the SOLAR 929 absorption spectrophotometer (ATI Unicam Ltd., UK). In 2009-2011, the quantity of fresh and dry matter of catch crops and the content of accumulated macronutrients were determined.

\section{Statistical analysis}

The results were statistically processed with ANOVA for the split-block design. The significance of differences was determined with Tukey's test at the significance level of $\mathrm{P} \leq 0.05$. All the calculations were performed with the Statistica software (version 10, Statsoft, USA).

\section{Weather conditions}

The basic weather conditions of the experimental area in individual growing seasons are presented in Table 4. Years 2010 and 2012 were characterized by similar average temperatures during the growing period and favourable precipitation distribution for the growth and development of broccoli. The least favourable conditions were in 2011, with higher mean air temperatures than in the other growing seasons, but with insufficient quantity of precipitation.

Table 4. Weather condition in the experiment area, 2010-2012 (Zawady Meteorological Station, Poland)

\begin{tabular}{c|c|c|c|c|c|c}
\hline \multirow{2}{*}{ Month } & \multicolumn{2}{|c|}{$\mathbf{2 0 1 0}$} & \multicolumn{2}{|c|}{$\mathbf{2 0 1 1}$} & \multicolumn{2}{c}{$\mathbf{2 0 1 2}$} \\
\cline { 2 - 6 } & $\mathbf{T}\left({ }^{\circ} \mathbf{C}\right)$ & $\mathbf{P}(\mathbf{m m})$ & $\mathbf{T}\left({ }^{\circ} \mathbf{C}\right)$ & $\mathbf{P}(\mathbf{m m})$ & $\mathbf{T ~}\left({ }^{\circ} \mathbf{C}\right)$ & $\mathbf{P}(\mathbf{m m})$ \\
\hline April & 8.9 & 10.7 & 10.1 & 31.0 & 8.9 & 29.9 \\
May & 14.0 & 93.2 & 13.4 & 36.1 & 14.6 & 53.4 \\
June & 17.4 & 62.6 & 18.1 & 39.1 & 16.3 & 76.2 \\
\hline Mean & 13.4 & - & 13.9 & - & 13.3 & - \\
\hline Total & - & 166.5 & - & 106.2 & - & 159.5 \\
\hline
\end{tabular}

$\mathrm{T}$ - average temperature, $\mathrm{P}-$ sum of precipitation

\section{Results and Discussion}

The quantity of incorporated fresh and dry matter and macronutrient content in catch crops varied across the years of research (Table 3). On average, between 2009 and 2011, the highest yields of fresh matter were recorded for winter rye $\left(35.5 \mathrm{t} \cdot \mathrm{ha}^{-1}\right)$, and the lowest 
for white clover and Italian ryegrass. The amount of dry matter (DM) in incorporated winter rye $\left(7.3 \mathrm{t} \cdot \mathrm{ha}^{-1}\right)$ was similar to the amount of DM in the incorporated farmyard manure (FYM) with an average of $7.6 \mathrm{t} \cdot \mathrm{ha}^{-1} \mathrm{DM}$. The least DM was produced by white clover (TR). O'Reilly et al. (2011) and Dolijanovic et al. (2012) report that the biomass produced by the catch crops of rye and hairy vetch can correspond even to $30 \mathrm{t} \cdot \mathrm{ha}^{-1} \mathrm{FYM}$.

The highest amount of $\mathrm{N}$ was in incorporated winter rye (SC). Its amounts accumulated by hairy vetch (VV) catch crops were similar, whereas in TR and LM the content of this macronutrient was significantly lower than in FYM. The quantity of P in SC was similar to that of FYM. Non-leguminous catch crops and FYM contained significantly more K than leguminous catch crops. SC accumulated significantly more $\mathrm{Ca}$ and $\mathrm{Mg}$ than $\mathrm{VV}$, TR, and LM. Incorporated FYM introduced the most $\mathrm{Ca}$ and $\mathrm{Mg}$ into the soil. The total amount of macronutrients accumulated by the catch crops constituted 40-122\% of the quantity introduced with $30 \mathrm{t} \cdot \mathrm{ha}^{-1} \mathrm{FYM}$. Thorup-Kristensen (2001) and Kramberger et al. (2009) reported that rye was one of the most effective catch crop plants recovering nutrients from deeper soil strata. The quantity of macronutrients in catch crops depends on a number of factors, including plant species, soil type, climatic conditions, and timing of cultivation. $\mathrm{N}$ is the element which exerts the greatest effect on the yield. The amounts of $\mathrm{N}$ in hairy vetch may range from 52 to $227 \mathrm{~kg} \cdot \mathrm{ha}^{-1}$ (Caporali et al., 2004; Franczuk, 2006; Salmerón et al., 2011). White clover leave soil in good condition, fixing from 100 to $240 \mathrm{~N} \cdot \mathrm{ha}^{-1}$ (Kärner and Kärner, 1996; Kramberger et al., 2014). In turn, rye may enrich the soil with 40-143 $\mathrm{kg} \mathrm{N} \cdot \mathrm{ha}^{-1}$ (Thorup-Kristensen, 2001; Franczuk, 2006).

Weather conditions in the successive growing seasons had a significant influence on the marketable yield of broccoli curds, mass of the marketable curd, and biological parameters (Tables 5-6). The highest marketable yield $\left(26.3 \mathrm{t} \cdot \mathrm{ha}^{-1}\right)$ and the highest weight of the curd $(696.3 \mathrm{~g}$ ) was in 2010, the most favourable for broccoli growth (Table 5). Both broccoli cultivars tested in the experiment produced similar yields, but the Loreto $\mathrm{F}_{1}$ cultivar developed slightly bigger curds than Milady $\mathrm{F}_{1}$. Statistical analysis of the results showed a significant effect of the types of organic fertilizer on broccoli yields. On average, across the growing seasons the largest marketable yield of curds $\left(27.9 \mathrm{t} \cdot \mathrm{ha}^{-1}\right)$ was on plots where in the previous year manure (FYM) was applied to sweet corn. A similar yield of curds was recorded in plants grown after incorporated hairy vetch (VV), white clover (TR), and winter rye (SC). Compared with control plants the commercial yield of broccoli from the FYM and VV plots was greater by $64 \%$ and $42 \%$, respectively, with these differences being statistically significant. An increase in the yield of broccoli grown after the other catch crops was 8-34\% greater than in the control plot, but the results were not statistically significant.

The largest broccoli curds $(725.9 \mathrm{~g})$ were harvested on plots where manure was applied to sweet corn (Table 5) in the previous year. A weight similar to the above, with a borderline statistical significant difference, was recorded for broccoli plants grown after VV, TR, and SC incorporation. In addition, broccoli preceded by FYM, VV, TR, and SC in crop rotation developed curds of a substantially greater weight than the control plants. de Freitas et al. (2011), using green manure (GM) of legume plants at doses of 5.0 and $2.5 \mathrm{t} \cdot \mathrm{ha}^{-1} \mathrm{DM}$ before planting broccoli, obtained curds with a mass greater by 180 and $120 \%$ than those in the control plot (without fertilization). However, production effects of green manure were worse than those obtained on plots with intensive mineral fertilizer treatment. An increase in the production of broccoli after GM was also recorded by Diniz et al. (2015), who observed that the yield of curds increased with an increase in a dose of GM biomass. Peralta-Antonio et al. (2019) suggest that on soils with average fertility, 
GM used on its own is insufficient to significantly affect the growth and yield of broccoli. Combined use of mineral fertilizer and GM is necessary, which is a viable option to reduce the amounts of the former. Production results of such combined application are similar to those obtained with high doses of mineral fertilizers.

Table 5. Effect of winter catch crop on the yield of broccoli and the weight of curds

\begin{tabular}{|c|c|c|c|c|c|c|}
\hline \multirow{2}{*}{ Organic manure } & \multicolumn{3}{|c|}{ Year } & \multicolumn{2}{|c|}{ Broccoli cultivar } & \multirow{2}{*}{ Mean } \\
\hline & 2010 & 2011 & 2012 & Loreto $F_{1}$ & Milady $F_{1}$ & \\
\hline \multicolumn{7}{|c|}{ Marketable yield $\left(\mathrm{t} \cdot \mathrm{ha}^{-1}\right)$} \\
\hline Control & 17.5 & 18.4 & 15.0 & 16.5 & 17.5 & $17.0^{\mathrm{a}}$ \\
\hline FYM & 31.4 & 25.8 & 26.5 & 27.2 & 28.7 & $27.9^{c}$ \\
\hline VV & 30.1 & 19.2 & 23.1 & 26.8 & 21.5 & $24.1^{\mathrm{bc}}$ \\
\hline TR & 30.9 & 16.9 & 20.7 & 22.6 & 23.1 & $22.8^{\mathrm{abc}}$ \\
\hline $\mathrm{SC}$ & 26.9 & 20.0 & 19.0 & 22.9 & 20.9 & $21.9^{\mathrm{abc}}$ \\
\hline LM & 21.0 & 18.0 & 16.1 & 18.8 & 17.9 & $18.4^{\mathrm{ab}}$ \\
\hline Mean & $26.3^{\mathrm{B}}$ & $19.7^{\mathrm{A}}$ & $20.1^{\mathrm{A}}$ & 22.4 & 21.6 & 22.0 \\
\hline \multicolumn{7}{|c|}{$H S D_{0.05}:$ year $=3.8$, broccoli cultivar $=\mathrm{NS}$, organic manuring $=6.8$, interactions $=\mathrm{NS}$} \\
\hline & \multicolumn{6}{|c|}{ Weight of marketable curd (g) } \\
\hline Control & 481.1 & 512.0 & 470.3 & $464.0^{\mathrm{a}}$ & $511.5^{\mathrm{a}}$ & $487.8^{\mathrm{a}}$ \\
\hline FYM & 795.3 & 678.6 & 703.8 & $694.6^{\mathrm{cd}}$ & $757.3^{\mathrm{b}}$ & $725.9^{\mathrm{c}}$ \\
\hline VV & 796.3 & 550.9 & 639.2 & $742.7^{\mathrm{d}}$ & $581.6^{\mathrm{a}}$ & $662.2^{\mathrm{bc}}$ \\
\hline TR & 813.8 & 523.1 & 564.9 & $638.7^{\mathrm{bcd}}$ & $629.2^{\mathrm{a}}$ & $633.9^{\mathrm{bc}}$ \\
\hline $\mathrm{SC}$ & 698.2 & 622.3 & 503.9 & $626.0^{\mathrm{bc}}$ & $590.2^{\mathrm{a}}$ & $608.1^{\mathrm{abc}}$ \\
\hline LM & 592.9 & 543.6 & 470.7 & $551.8^{\mathrm{ab}}$ & $519.6^{\mathrm{a}}$ & $535.7^{\mathrm{ab}}$ \\
\hline Mean & $696.3^{\mathrm{B}}$ & $571.7^{\mathrm{A}}$ & $558.8^{\mathrm{A}}$ & 619.6 & 598.2 & 608.9 \\
\hline
\end{tabular}

Means followed by different lowercase letters in columns and different uppercase letters in rows differ significantly at $\mathrm{p} \leq 0.05 ; \mathrm{FYM}$ - fermyard manure, VV - hairy vetch, TR - white clover, SC - winter rye, LM - Italian ryegrass; NS - not significant

In the present experiment significant interaction of broccoli cultivars with organic fertilisers was recorded. The Loreto $F_{1}$ cultivar grown after VV (742.7 g) produced the biggest curds, with similar results recorded when it followed incorporated FYM or when it followed TR and SC. However, when it was grown after FYM incorporation, the Milady $\mathrm{F}_{1}$ cultivar produced significantly the largest curds (757.3 g).

Hairy vetch, white clover and winter rye cultivated as winter catch crops may successfully replace farmyard manure. Many researchers point to their short-term and long-term effects on the yields of subsequent crops (Salmerón et al., 2011; Choi et al., 2014; Zandvakili et al., 2017; Makarewicz et al., 2018; Thavarajah et al., 2019). However, the yield is not the only reason why catch crops should be included into crop rotation. They should be planted due to ecological reasons, such as reduction of weed infestation and herbicide use, limitation of soil erosion, recovery of nutrients from deeper soil strata and protection against them being leached out into groundwater, an increase in the amount of organic matter, as well as a positive reaction of micro and mesofauna in the soil (Hartwig and Ammon, 2002; Snapp et al., 2005; Reddy, 2016).

In 2010 broccoli plants had stems with a larger diameter than those grown in 2012. Plants grown in 2010 and 2012 had a longer curd arc than in 2011 (Table 6). Organic 
fertilisers also differentiated the biometric parameters of broccoli curds. Across the growing seasons, the largest stem diameter and the longest curd arc were recorded in broccoli grown on plots with manure applied to sweet corn the previous year $(4.02 \mathrm{~cm}$ and $33.7 \mathrm{~cm}$, respectively). Similar values were also found in plants grown after VV. As an average for all treatments the Loreto $F_{1}$ cultivar developed longer curd arcs than the Milady $F_{1}$ cultivar.

Table 6. Effect of winter catch crop on broccoli curd biological parameters

\begin{tabular}{|c|c|c|c|c|c|c|}
\hline \multirow{2}{*}{ Organic manure } & \multicolumn{3}{|c|}{ Year } & \multicolumn{2}{|c|}{ Broccoli cultivar } & \multirow{2}{*}{ Mean } \\
\hline & 2010 & 2011 & 2012 & Loreto $F_{1}$ & Milady $F_{1}$ & \\
\hline \multicolumn{7}{|c|}{ Stalk diameter $(\mathrm{cm})$} \\
\hline Control & $3.68^{\mathrm{ab}}$ & $3.85^{\mathrm{bc}}$ & 3.19 & $3.49^{\mathrm{a}}$ & $3.65^{\mathrm{c}}$ & $3.57^{\mathrm{a}}$ \\
\hline FYM & $4.14^{\mathrm{b}}$ & $4.31^{\mathrm{c}}$ & 3.60 & $3.98^{\mathrm{c}}$ & $4.06^{\mathrm{d}}$ & $4.02^{\mathrm{b}}$ \\
\hline VV & $3.86^{\mathrm{ab}}$ & $3.68^{\mathrm{abc}}$ & 3.56 & $3.88^{\mathrm{bc}}$ & $3.52^{\mathrm{abc}}$ & $3.70^{\mathrm{ab}}$ \\
\hline TR & $3.43^{\mathrm{a}}$ & $3.09^{\mathrm{a}}$ & 3.45 & $3.45^{\mathrm{a}}$ & $3.19^{\mathrm{a}}$ & $3.32^{\mathrm{a}}$ \\
\hline $\mathrm{SC}$ & $3.44^{\mathrm{a}}$ & $3.18^{\mathrm{a}}$ & 3.44 & $3.43^{\mathrm{a}}$ & $3.28^{\mathrm{ab}}$ & $3.35^{\mathrm{a}}$ \\
\hline LM & $3.61^{\mathrm{ab}}$ & $3.57^{\mathrm{ab}}$ & 3.57 & $3.56^{\mathrm{ab}}$ & $3.61^{\mathrm{bc}}$ & $3.58^{\mathrm{a}}$ \\
\hline Mean & $3.69^{\mathrm{B}}$ & $3.61^{\mathrm{AB}}$ & $3.47^{\mathrm{A}}$ & 3.63 & 3.55 & 3.59 \\
\hline \multicolumn{7}{|c|}{$\begin{array}{c}H S D_{0.05}: \text { year }=0.17, \text { broccoli cultivar }=\mathrm{NS}, \text { organic manuring }=0.39, \text { year } \times \text { organic manuring }=0.66, \text { broccoli } \\
\text { cultivar } \times \text { organic manuring }=0.35, \text { other interactions }=\mathrm{NS}\end{array}$} \\
\hline & \multicolumn{6}{|c|}{ Curd circumference length $(\mathrm{cm})$} \\
\hline Control & 34.05 & 24.77 & 31.07 & 31.01 & 28.91 & $29.96^{\mathrm{a}}$ \\
\hline FYM & 38.15 & 28.88 & 34.03 & 35.69 & 31.69 & $33.69^{b}$ \\
\hline VV & 37.32 & 25.95 & 36.78 & 36.06 & 30.63 & $33.34^{\mathrm{b}}$ \\
\hline TR & 32.40 & 22.68 & 33.13 & 30.98 & 27.83 & $29.40^{\mathrm{a}}$ \\
\hline $\mathrm{SC}$ & 31.95 & 21.05 & 32.22 & 29.63 & 27.18 & $28.41^{\mathrm{a}}$ \\
\hline LM & 32.17 & 22.18 & 32.25 & 29.29 & 28.44 & $28.87^{\mathrm{a}}$ \\
\hline Mean & $34.34^{\mathrm{B}}$ & $24.25^{\mathrm{A}}$ & $33.25^{\mathrm{B}}$ & $32.11^{\mathrm{B}}$ & $29.11^{\mathrm{A}}$ & 30.61 \\
\hline
\end{tabular}

Means followed by different lowercase letters in columns and different uppercase letters in rows differ significantly at $\mathrm{p} \leq 0.05 ; \mathrm{FYM}$ - fermyard manure, VV - hairy vetch, TR - white clover, SC - winter rye, LM - Italian ryegrass; NS - not significant

The average content of dry matter in broccoli curds was $8.51 \%$, with protein constituting $4.17 \% \mathrm{FM}$ (fresh matter), ascorbic acid $71.76 \mathrm{mg} \cdot 100 \mathrm{~g}^{-1} \mathrm{FM}$, and total sugars $2.78 \mathrm{~g} \cdot 100 \mathrm{~g}^{-1} \mathrm{FM}$ (Table 7). Chemical composition of vegetables is genetically determined, but it is modified by factors affecting the plant during its growth (Lee and Kadar, 2000). In the present studies, the effects of weather conditions and organic fertilizers on the content of minerals and nutrients in broccoli were significant. The plants produced the driest matter and total sugars in 2012, protein in 2011, and ascorbic acid in 2011 and 2012. The smallest amounts of dry matter and ascorbic acid were in broccoli grown in 2010, protein in 2012, and total sugars in 2011.

Broccoli plants grown after sweet corn treated with incorporated SC, VV, and manure were significantly richer in protein than those grown in control. The difference was $0.24-0.32 \%$. Broccoli grown after SC contained more protein than after TR and LM. The highest amounts of total $\mathrm{N}$ (Table 3) were recorded in plants grown after manure (FYM), winter rye (SC), and hairy vetch (VV). After the mineralization of organic matter, taking place in the first and second years after catch crop incorporation, $\mathrm{N}$ became available to 
broccoli. Plants used it for tissue building and protein synthesis. In addition, broccoli plants grown on plots with incorporated TR and VV contained significantly more total sugars than those grown in control, respectively, by 0.21 and $0.19 \mathrm{~g} \cdot 100 \mathrm{~g}^{-1} \mathrm{FM}$. According to Worthington (2001) and Talgre et al. (2012), an increase in available $\mathrm{N}$ content stimulates protein production, which may explain increased protein content in plants following legume catch crops, those additional sources of available $\mathrm{N}$ living in symbiosis with $\mathrm{N}$-fixing bacteria. Increased content of protein and vitamin $\mathrm{C}$ was earlier recorded by Jabłońska-Ceglarek and Rosa (2003), who used spring-incorporated green manures.

Table 7. The content of selected components of nutritive value of broccoli

\begin{tabular}{|c|c|c|c|c|}
\hline Treatment & Dry matter (\%) & $\begin{array}{l}\text { Protein } \\
(\% \text { FM) }\end{array}$ & $\begin{array}{c}\text { Ascorbic acid } \\
\left(\mathrm{mg}^{\prime} \cdot 100 \mathrm{~g}^{-1} \text { FM }\right)\end{array}$ & $\begin{array}{c}\text { Total sugars } \\
\left(\mathrm{g} \cdot 100 \mathrm{~g}^{-1} \mathrm{FM}\right)\end{array}$ \\
\hline \multicolumn{5}{|l|}{ Years } \\
\hline 2010 & $7.58^{\mathrm{a}}$ & $4.15^{\mathrm{a}}$ & $69.81^{\mathrm{a}}$ & $2.81^{\mathrm{b}}$ \\
\hline 2011 & $8.56^{\mathrm{b}}$ & $4.30^{\mathrm{b}}$ & $72.40^{\mathrm{b}}$ & $2.62^{\mathrm{a}}$ \\
\hline 2012 & $9.39^{\mathrm{c}}$ & $4.05^{\mathrm{a}}$ & $73.08^{\mathrm{b}}$ & $2.92^{\mathrm{c}}$ \\
\hline \multicolumn{5}{|l|}{ Broccoli cultivar } \\
\hline Loreto $\mathrm{F}_{1}$ & 8.45 & $4.13^{\mathrm{a}}$ & $72.44^{\mathrm{b}}$ & $2.84^{\mathrm{b}}$ \\
\hline Milady $F_{1}$ & 8.57 & $4.21^{\mathrm{b}}$ & $71.08^{\mathrm{a}}$ & $2.72^{\mathrm{a}}$ \\
\hline \multicolumn{5}{|l|}{ Organic manure } \\
\hline Control & 8.28 & $4.00^{\mathrm{a}}$ & 71.79 & $2.66^{\mathrm{a}}$ \\
\hline FYM & 8.64 & $4.24^{\mathrm{bc}}$ & 73.02 & $2.80^{\mathrm{ab}}$ \\
\hline VV & 8.58 & $4.24^{\mathrm{bc}}$ & 73.19 & $2.85^{\mathrm{b}}$ \\
\hline TR & 8.53 & $4.10^{\mathrm{ab}}$ & 70.22 & $2.87^{\mathrm{b}}$ \\
\hline $\mathrm{SC}$ & 8.69 & $4.32^{\mathrm{c}}$ & 70.68 & $2.79^{\mathrm{ab}}$ \\
\hline LM & 8.32 & $4.10^{\mathrm{ab}}$ & 71.66 & $2.73^{\mathrm{ab}}$ \\
\hline Mean & 8.51 & 4.17 & 71.76 & 2.78 \\
\hline \multicolumn{5}{|c|}{$\begin{array}{c}H S D_{0.05} \text { for dry matter: years }=0.79, \text { broccoli cultivar }=\mathrm{NS}, \text { organic manure }=\mathrm{NS} \\
H S D_{0.05} \text { for protein: years }=0.11, \text { broccoli cultivar }=0.07, \text { organic manure }=0.16 \\
H S D_{0.05} \text { for ascorbic acid: years }=2.02, \text { broccoli cultivar }=1.32, \text { organic manure }=\mathrm{NS} \\
H S D_{0.05} \text { for total sugars: years }=0.10, \text { broccoli cultivar }=0.07, \text { organic manure }=0.17\end{array}$} \\
\hline
\end{tabular}

Means followed by different letters in columns differ significantly at $p \leq 0.05$; FYM - farmyard manure, VV - hairy vetch, TR - white clover, SC - winter rye, LM - Italian ryegrass; FM - fresh matter; NS not significant

The content of the nutrients was also dependent on the broccoli cultivar. The Loreto $\mathrm{F}_{1}$ cultivar contained more ascorbic acid and total sugars, but less protein than Milady $\mathrm{F}_{1}$.

Between 2011 and 2012 concentrations of $\mathrm{P}, \mathrm{K}, \mathrm{Ca}$, and $\mathrm{Mg}$ were determined in broccoli curds. In 2011 plants contained significantly less $\mathrm{P}$ and $\mathrm{Ca}$, but significantly more $\mathrm{Mg}$ than in 2012 (Table 8). Both varieties contained similar amounts of $\mathrm{P}, \mathrm{K}$, and $\mathrm{Ca}$, while the Loreto $\mathrm{F}_{1}$ cultivar contained significantly more $\mathrm{Mg}$. The catch crops and manure, both incorporated before sweet corn, had a significant impact on the concentrations of $\mathrm{P}, \mathrm{K}$ and $\mathrm{Mg}$ in broccoli. The most $\mathrm{P}$ was recorded in broccoli grown after VV and TR as winter catch crops, significantly more than in control plants and more than plants on plots preceded by FYM and LM. Significantly the most K was recorded in broccoli grown after FYM and VV. Broccoli plants grown after VV were also the richest in $\mathrm{Mg}$. The approximate amount of this element was recorded in broccoli grown after incorporated manure and TR. 
Table 8. Concentrations of macronutrients in broccoli

\begin{tabular}{|c|c|c|c|c|}
\hline \multirow{2}{*}{ Treatment } & $\mathbf{P}$ & $\mathbf{K}$ & $\mathbf{C a}$ & Mg \\
\hline & \multicolumn{4}{|c|}{$\left(\mathrm{g} \cdot \mathrm{kg}^{-1} \mathrm{DM}\right)$} \\
\hline \multicolumn{5}{|l|}{ Years } \\
\hline 2011 & $4.53^{\mathrm{a}}$ & 23.0 & $3.33^{\mathrm{a}}$ & $2.16^{\mathrm{b}}$ \\
\hline 2012 & $5.23^{\mathrm{b}}$ & 22.8 & $3.37^{\mathrm{b}}$ & $2.01^{\mathrm{a}}$ \\
\hline \multicolumn{5}{|l|}{ Broccoli cultivar } \\
\hline Loreto $\mathrm{F}_{1}$ & 4.89 & 22.9 & 3.34 & $2.11^{\mathrm{b}}$ \\
\hline Milady $F_{1}$ & 4.87 & 22.8 & 3.36 & $2.06^{\mathrm{a}}$ \\
\hline \multicolumn{5}{|l|}{ Organic manure } \\
\hline Control & $4.36^{\mathrm{a}}$ & $22.4^{\mathrm{a}}$ & 3.29 & $1.99^{\mathrm{a}}$ \\
\hline FYM & $4.62^{\mathrm{ab}}$ & $23.5^{b}$ & 3.38 & $2.15^{\mathrm{bc}}$ \\
\hline VV & $5.39^{c}$ & $23.4^{\mathrm{b}}$ & 3.37 & $2.20^{\mathrm{c}}$ \\
\hline TR & $5.25^{\mathrm{c}}$ & $22.8^{\mathrm{a}}$ & 3.36 & $2.13^{\mathrm{bc}}$ \\
\hline $\mathrm{SC}$ & $4.91^{\mathrm{bc}}$ & $22.5^{\mathrm{a}}$ & 3.32 & $2.06^{\mathrm{ab}}$ \\
\hline LM & $4.76^{\mathrm{ab}}$ & $22.6^{\mathrm{a}}$ & 3.38 & $1.99^{\mathrm{a}}$ \\
\hline \multirow[t]{2}{*}{ Mean } & 4.88 & 22.9 & 3.35 & 2.09 \\
\hline & $\begin{array}{l}\text { ears }=0 \\
\text { years }= \\
\text { years }= \\
\text { years }=\end{array}$ & $\begin{array}{l}\text { cultivar } \\
\text { cultivar } \\
\text { i cultiva } \\
\text { cultivar }\end{array}$ & $\begin{array}{l}\text { manur } \\
\text { manur } \\
\text { manu } \\
\mathrm{c} \text { manu }\end{array}$ & \\
\hline
\end{tabular}

Means followed by different letters in columns differ significantly at $p \leq 0.05$; FYM - farmyard manure, VV - hairy vetch, TR - white clover, SC - winter rye, LM - Italian ryegrass; DM - dry matter; NS - not significant

\section{Conclusions}

1. The effect of winter catch crops ploughed into the soil, like Vicia villosa Roth., Trifolium repens $\mathrm{L}$. and Secale cereale $\mathrm{L}$. on the broccoli yield was statistically similar to that of manure applied at a dose of $30 \mathrm{t} \cdot \mathrm{ha}^{-1}$. Among the above catch crops, hairy vetch affected the yield of subsequent crops the most.

2. Organic fertilisers applied to the crops preceding broccoli affected its content of protein and sugars. A significant increase in protein content in relation to control was observed in broccoli plants grown after farmyard manure and incorporated hairy vetch and winter rye treatments, and in total sugars after hairy vetch and white clover.

3. The largest $\mathrm{P}$ concentration was in broccoli grown after hairy vetch and white clover, while the largest amounts of $\mathrm{K}$ was after farmyard manure application and after hairy vetch incorporation, and $\mathrm{Mg}$ when broccoli was grown after hairy vetch.

4. Broccoli varieties produced similar yields. The Loreto $F_{1}$ cultivar contained more ascorbic acid, total sugars and $\mathrm{Mg}$, but less protein than the Milady $\mathrm{F}_{1} \mathrm{cv}$.

5. It was found that in horticulture, winter catch crops like hairy vetch, white clover and winter rye can be an alternative for manure, an organic fertiliser increasingly more difficult to obtain. The beneficial effect of those crops, similar to the effect of manure, on the yield of following crops was also evident in the second year. They can be successfully used in the following sequence: winter catch crops - sweet corn - broccoli.

6. The results of the research allowed to issue practical recommendations to farmers on the use of these catch crops in the cultivation of sweet corn and broccoli.

7. Research on other plants and their mixtures is still necessary to replace FYM and to reduce mineral fertilisation in vegetable cultivation. 
Acknowledgements. The research carried out under the theme No. 226/06/S was financed by the science grant of the Ministry of Science and Higher Education.

\section{REFERENCES}

[1] Adamczewska-Sowińska, K., Kołota, E. (2008): The effect of living mulches on yield and quality of tomato fruits. - Vegetable Crops Research Bulletin 69(1): 31-38. DOI: 10.2478/v10032-008-0018-z.

[2] AOAC (1984): Association of Official Analytical Chemists. Official methods of analysis. 14th ed. Assn. - Official Analytical Chemists, Arlington, Va. sec. 14.067.

[3] Caporali, F., Campiglia, E., Mancinelli, R., Paolini, R. (2004): Maize performances as influenced by winter cover crop green manure. - Italian Journal of Agronomy 8(1): 37-45.

[4] Choi, B., Lim, J. E., Sung, J. K., Jeon, W. T., Lee, S. S., Oh, S.-E., Yang, J. E., Ok, Y. S. (2014): Effect of Rapeseed green manure amendment on soil properties and rice productivity. - Communications in Soil Science and Plant Analysis 45(6): 751-764. DOI: 10.1080/00103624.2013.858728.

[5] de Freitas, G. B., Rocha, M. S., Santos, R. H. S., Monteiro da Silva Freitas, L., de Almeida Resende, L. (2011): Broccoli yield in response to top-dressing fertilization with green manure and biofertilizer. - Revista Ceres 58(5): 645-650. DOI: 10.1590/s0034737x2011000500016.

[6] Diniz, E. R., de Oliveira Vargas, T., Santos, R. H. S., de Almeida, A. R., de Mattos, U. B. M. (2015): Crescimento e produção de brócolis adubado com doses de mucuna-cinza em casa de vegetação. - Semina: Ciências Agrárias 36(3): 1277-1286. DOI: 10.5433/16790359.2015v36n3p1277.

[7] Dolijanovic, Z., Momirovic, N., Mihajlovic, V., Simic, M., Oljaca, S., Kovacevic, D., Kaitovic, Z. (2012): Cover crops effects on the yield of sweet corn. - Third International Scientific Sympozjum “Agrosym Jahorina 2012”: 104-110.

[8] EU (2009): Commission Regulation No. 152/2009. - Official Journal of the European Union L54: 1-130.

[9] FAOSTAT (2018): Broccoli (and cauliflower) production in 2018, Crops/Regions/World list/Production Quantity (pick lists). - UN Food and Agriculture Organization, Corporate Statistical Database. Retrieved 9 March 2020.

[10] Fekete, Á., Pepó, P. (2018): The role of green manure crops in Hungarian plant production. - Acta Agraria Debreceniensis 74: 49-53. DOI: 10.34101/actaagrar/74/1663.

[11] Franczuk, J. (2006): Efekty stosowania nawozów zielonych w postaci międzyplonów ozimych oraz słomy żytniej w uprawie warzyw. (The effects of the use of green manure in the form of winter catch crops and rye straw in the cultivation of vegetables). Wydawnictwo Akademii Podlaskiej w Siedlcach, Rozprawa Nauk 84: 122 p. (in Polish).

[12] Hartwig, N., Ammon, H. (2002): Cover crops and living mulches. - Weed Sciences 50(6): 688-699.

[13] Iivonen, S., Kivijärvi, P., Suojala-Ahlfors, T. (2017): Characteristics of various catch crops in the organic vegetable production in northern climate conditions - Results from and onfarm study. Reports 165. - University of Helsinki, Ruralia Institute, http://hdl.handle.net/10138/229443.

[14] IUSS Working Group WRB (2015): World Reference Base for Soil Resources 2014 (update 2015). - International Soil Classification System for Naming Soils and Creating Legends for Soil Maps, World Soil Resources Reports No. 106. Rome, FAO.

[15] Jabłońska-Ceglarek, R., Rosa, R. (2003): Influence of green manures on the quantity and quality of the yield of red beet. - Acta Scientiarum Polonorum, Hortorum Cultus 2(1): 2130. (in Polish with English summary).

[16] Kärner, M., Kärner, E. (1996): White clover as a source of N on Estonian grassland on acid soils poor in humus. - REUR Technical Series 42: 104-106. 
[17] Kramberger, B., Gselman, A., Janzekovic, M., Kaligaric, M., Bracko, B. (2009): Effects of cover crops on soil mineral $\mathrm{N}$ and on the yield and $\mathrm{N}$ content of maize. - European Journal of Agronomy 31(2): 103-109. DOI: 10.1016/j.eja.2009.05.006.

[18] Kramberger, B., Gselman, A., Kristl, J., Lešnik, M., Šuštar, V., Muršec, M., Podvršnik, M. (2014): Winter cover crop: the effects of grass-clover mixture proportion and biomass management on maize and the apparent residual $\mathrm{N}$ in the soil. - European Journal of Agronomy 55: 63-71. DOI: 10.1016/j.eja.2014.01.001.

[19] Kristensen, H., Thorup-Kristensen, K. (2004): Root growth and nitrate uptake of three different catch crops in deep soil layers. - Soil Science Society of America Journal 68(2): 529-537. DOI: 10.2136/sssaj2004.5290.

[20] Lee, S. K., Kader, A. A. (2000): Preharvest and postharvest factors influencing vitamin C content of horticultural crops. - Postharvest Biology and Technology 20(3): 207-220. DOI: 10.1016/s0925-5214(00)00133-2.

[21] Makarewicz, A., Płaza, A., Gąsiorowska, B., Rosa, R., Cybulska, A., Górski, R., Rzążewska, E. (2018): Effect of manure with undersown catch crops and production system on the potato tuber content of macroelements. - Journal of Elementology 23(1): 7-19. DOI: 10.5601/jelem.2017.22.1.1398.

[22] O'Reilly, K. A., Robinson, D. E., Vyn, R. J., van Eerd, L. L. (2011): Weed populations, sweet corn yield, and economics following fall cover crops. - Weed Technology 25(3): 374-384. DOI: $10.1614 /$ wt-d-10-00051.1.

[23] Parente, C. P., Reis Lima, M. J., Teixeira-Lemos, E., Moreira, M. M., Barros, A. A., Guido, L. F. (2013): Phenolic content and antioxidant activity determination in broccoli and lamb's lettuce. - International Journal of Agricultural and Biosystems Engineering 7: 70-73.

[24] Peralta-Antonio, N., Watthier, M., Santos, R. H. S., Martinez, H. E. P., Vergütz, L. (2019): Broccoli nutrition and changes of soil solution with green manure and mineral fertilization. - Journal of Soil Science and Plant Nutrition 19(4): 816-829. DOI: 10.1007/s42729-01900081-4.

[25] PN-A-04019 (1998): Polish Standard. Food products - Determination of vitamin C content. - Polish Committee for Standardization, Warsaw, Poland. (in Polish).

[26] Polish Standard PN-EN 12145 (2001): Fruit and vegetable juices - Determination of total dry matter - Gravimetric method with loss of mass on drying. - Polish Committee for Standardization, Warsaw, Poland. (in Polish).

[27] Reddy, P. P. (2016): Cover/Green Manure Crops. - Sustainable Intensification of Crop Production: 55-67. DOI: 10.1007/978-981-10-2702-4_4.

[28] Rogers, G. S., Little, S. A., Silcock, S. J., Williams, L. F. (2004): No-till vegetable production using organic mulches. - Acta Horticulturae 638: 215-223. DOI: 10.17660/actahortic.2004.638.28.

[29] Rosa, R. (2014): The structure and yield level of sweet corn depending on the type of winter catch crops and weed control method. - Journal of Ecological Engineering 15(4): 118-130. DOI: $10.12911 / 22998993.1125466$.

[30] Rosa, R. (2015): Quality of sweet corn yield depending on winter catch crops and weed control method. - Acta Scientiarum Polonorum, Hortorum Cultus 14(2): 59-74.

[31] Salmerón, M., Isla, R., Cavero, J. (2011): Effect of winter cover crop species and planting methods on maize yield and $\mathrm{N}$ availability under irrigated Mediterranean conditions. Field Crops Research 123(2): 89-99. DOI: 10.1016/j.fcr.2011.05.006.

[32] Snapp, S. S., Swinton, S. M., Labarta, R., Mutch, D., Black, J. R., Leep, R., Nyiraneza, J., O'Neil, K. (2005): Evaluating cover crops for benefits, costs and performance within cropping system niches. - Agronomy Journal 97: 322-332. DOI: 10.2134/agronj2005.0322.

[33] Talgre, L., Lauringson, E., Roostalu, H., Astover, A., Makke, A. (2012): Green manure as a nutrient source for succeeding crops. - Plant, Soil and Environment 58(6): 275-281. DOI: 10.17221/22/2012-pse. 
[34] Thavarajah, D., Siva, N., Johnson, N., McGee, R., Thavarajah, P. (2019): Effect of cover crops on the yield and nutrient concentration of organic kale (Brassica oleracea L. var. acephala). - Scientific Reports 9: 10374. DOI: 10.1038/s41598-019-46847-9.

[35] Thorup-Kristensen, K. (2001): Are differences in root growth of N catch crops important for their ability to reduce soil nitrate-N content, and how can this be measured? - Plant and Soil 230: 185-195.

[36] Vos, J., van der Putten, P. E. L. (2001): Field observations on N catch crops. III. Transfer of $\mathrm{N}$ to the succeeding main crop. - Plant and Soil 236: 263-273.

[37] Worthington, V. (2001): Nutritional quality of organic versus conventional fruits, vegetables and grains. - The Journal of Alternative and Complementary Medicine 7(2): 161-173.

[38] Zandvakili, O. R., Ebrahimi, E., Hashemi, M., Barker, A. V., Akbari, P. (2017): The potential of green manure mixtures to provide nutrients to a subsequent lettuce crop. Communications in Soil Science and Plant Analysis 48(19): 2246-2255. DOI: 10.1080/00103624.2017.1408819.

[39] Zhang, Y., Gao, L., Zhou, W., Li, Z. (2010): Effects of intercropping clover on yield, quality of sweet corn and soil mineral $\mathrm{N}$ in field. - Acta Agriculturae Boreali-Sinica S1: 236-238. 